\title{
オープンツースソフトウェアを用いサ

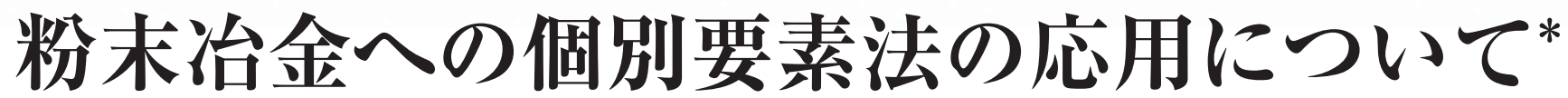 \\ Application of Discrete Element Method to Powder Metallurgy with Open Source Software
}

\section{大塚 順 ${ }^{* *}$ 齋藤達哉 ${ }^{* * *}$ \\ Jun OTSUKA and Tatsuya SAITO}

Key words DEM, powder metallurgy, feeding, ball mill, supercomputer

\section{1. 緒言}

粉末治金は, 金属粉末を金型に充填してプレス機で圧縮 して固めた後に焼結して製品を製造する技術であり，高精 度かつ大量生産に向いており素形材産業の重要技術であ る。しかし，環境変化が粉体挙動に複雑かつ顕著に影響す るため, 製造条件と製品品質との間で因果関倸を明瞭化す ることが難しい，近年，精度要求はますます厳しくなって おり，製造条件の確立に要する試作回数が増大しているた め, 開発リードタイムを短縮するための打開策としてシミ ユレーション技術が切望されている。代表的な粉体シミュ レーション法として個別要素法 (DEM : Discrete Element Method $)^{1)}$ が知られている. 粉体を構成する一つ一つの粒 子の運動を運動方程式に基づいて追跡する手法であり，粉 体挙動の特徴を忠実に表現することができる ${ }^{2)}$. 図 1 に計 算アルゴリズムのイメージを示す。粒子間接触力は, バネ とダッシュポットによりシンプルに表現されており, 汎用 性の高さが特長である。著者らは粉末治金の各工程への DEM の適用可能性を評価するべく，これまでに供給工 程3), 粉砕工程 ${ }^{45)}$, 混合工程, 給粉工程などのシミュレー トを試みてきた

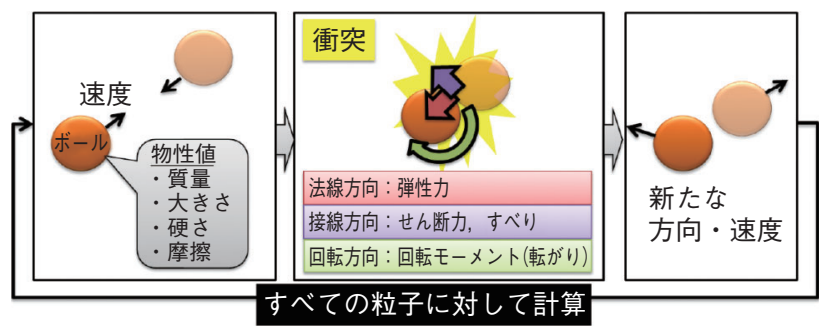

図 1 個別要素法（DEM）を用いた粉体粒子の挙動シミュレーショ ンのアルゴリズム

*原稿受付 平成 30 年 4 月 19 日

*住友電気工業(株)（神奈川県横浜市栄区田谷町 1)

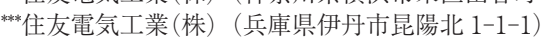

実プロセスに適用するときの課題は計算モデル規模, 適 切なモデルの構築である。例えば給粉工程の粉体挙動を解 析するのに実際の粒子を DEM シミュレーションしょうと すると, 粒子数が莫大になるため最新のスーパーコンピュ ー夕を利用したとしても現実的な時間で計算を完了できな い. 粉末の体積を一定にした状態で粒径を 2 倍にすると， 粒子数は $1 / 8$ 倍に削減できるため, 計算コス卜を低減する 方法として粗視化モデルがよく使わ机ている6). しかし， 粉末治金にDEM シミュレーションを応用するとき，例え ば給粉シミュレーションに扔いては, 金型形状の複雑さか ら給粉挙動が壁効果 ${ }^{7)}$ の影響を受けるため, 粗視化モデル の適用には限界があり, 大規模計算の実施が必要不可欠と なる。また，DEM シミュレーションでは粒子を球体とし て扱うため, 対象とする問題によっては実現象の再現が難 しいことがよく知られている。給粉シミュレーションを例 にとると，粒子の流れに関しては摩擦係数を調整すること である程度再現できるようだが, 辢密度に関しては異形状 性が直接影響するため通常の DEM では再現できない。こ の打開策として一つの異形状粒子を複数の微小粒子の複合 体として表現するクランプモデルが提案されており ${ }^{8)}$, 現 状の最有力手法と見なされているようである. 著者らが DEM シミュレータとして利用しているオープンソースソ フトウエア LIGGGHTS (LAMMPS IMPROVED FOR GENERAL GRANULAR AND GRANULAR HEAT TRANSFER SIMULATIONS) $\left.{ }^{9}\right)$ は, これらの課題に対処 できる機能が初期実装されている。 LIGGGHTS の事例は 最近いくつか報告されている ${ }^{10) 11}$. 首藤らは非球形粒子の 計算事例を報告している ${ }^{10)}$.

本稿では, ボールミルの粉砕工程と給粉工程を計算対象 として実施した，LIGGGHTSをスーパーコンピュータへ 移植した事例掞よび流体の影響を取り込むための粉体モデ ルのカスタマイズ, オープンソースの可視化ソフトウエア と組み合わせた解析システムの構築について紹介する。 


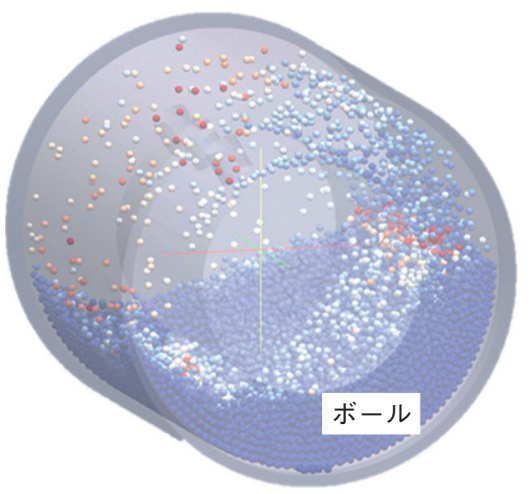

図 2 ボールミルのシミュレーション。ボールは速さに応じて色付 けしている。ミルのピンは透明表示している.

\section{2. ボールミルの粉砕シミュレーション}

\section{1 粉砕性の予測}

超硬合金は炭化物粉末および金属粉末が主原料であり， 湿式ボールミルを用いて混合・粉砕して所定の分散，粒度 にする。図 2 に簡易形状のボールミルを示す。ボールミ ルの容器にはボールと砕料が入れられるが，粉砕性の予測 はボールどうしの衝突エネルギーを評価すればよい ${ }^{12) 133}$. 衝突エネルギー $E_{w}$ は次式で計算できる。

$$
E_{w}=\frac{1}{W} \sum_{j=1}^{n} \frac{1}{2} m v_{j}^{2}
$$

ここで, $W$ は砕料重量, $n$ は衝突回数, $m$ はボールの質 量， $v_{j}$ は他のボールまたは壁面と衝突するときの相対速 度である，砕料を計算に直接含めることは困難なため，ボ 一ル運動に対する摩擦効果として取り込み，安息角を再現 するよう適切に摩擦係数を選択することでボール運動を精 度良く再現することができると報告されている ${ }^{12)}$ ．実際の ミル形状拉よびボール径をシミュレートするにはボール数 が膨大となり，社内で保有する解析サーバでは計算できな かったため大学のスーパーコンピュータを利用した。 ま た，スラリー中のボールの運動は流体抵抗により運動量が 小さくなることを表現するため LIGGGHTS のカスタマイ ズも行った

\section{2 スーパーコンピュータへの移植}

LIGGGHTS（version 2.24）のオリジナルのソースコー ドでは実効性能（実際の演算速度）が不十分だったため, 大幅な変更を伴わない範囲でソースコードを変更してチュ ーニングを実施した結果，3.4 倍のスピードアップを実現 した5)，256ノードを使用した MPI 並列計算により大規模 モデルを計算できるようになり，小径ボールの解析を実現 した.

\subsection{LIGGGHTS のカスタマイス}

スラリーの流れを数值流体解析で計算して DEM シミュ レーションと連成させる方法は，流体の影響を精度良く表 現することが可能だが ${ }^{14)}$ ，湿式ミルは内部構造が複雑であ り計算負荷が大きくなるため，実機のシミュレーションで

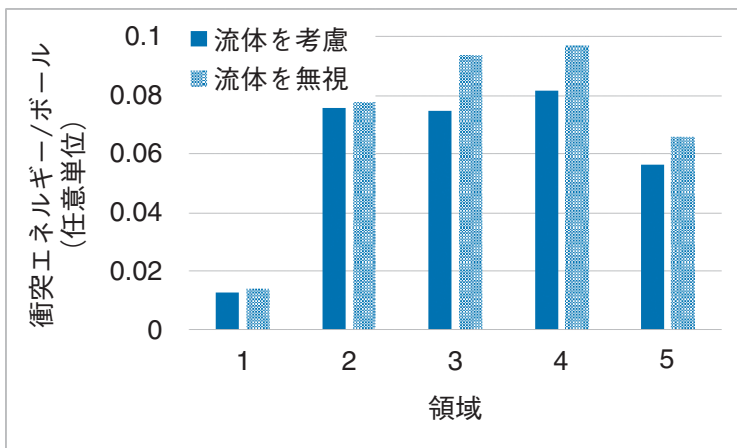

図 3 ボールの衝突エネルギー

は実施が困難である。そこで，ボールの動きによる流机場 への影響は無視してスラリーの流れ場を静的に与え，スラ リーからボールが受ける浮力 $F_{B}$ 打よび流体抵抗 $F_{D}$ を外 力としてモデル化する方法を ${ }^{12}$ 採用した。 浮力 $F_{B}$ 拉よび 流体抗力 $F_{D}$ は次式で表すことがでる.

$$
\begin{aligned}
& F_{B}=g V_{B} \rho_{s} \\
& F_{D}=C_{d} A \rho_{s} \frac{u_{r}^{2}}{2}
\end{aligned}
$$

ここで， $V_{B}$ はビーズ体積， $C_{d}$ は抵抗係数， $A$ は投影断面 積， $\rho_{s}$ はスラリー密度， ur は流体とビーズの相対速度で ある。流体抗力 $F_{D}$ は流体とボールの相対速度に依存する ことが分かる．LIGGGHTS には粒子に働く外力を追加亦 るためのコマンド “fix addforce”が実装されているが, もともとは一定值しか与えられない仕様であるため，この コマンドのソースコードを変更して流体抗力も表現できる ようにした

\section{4 ボール運動の解析結果}

図 3 に衝突エネルギーの解析結果を示す。ミルを適当 な五つの領域に分割して各領域に存在するボールに対して 衝突エネルギーを評価した。当初の予想ど㧍り，スラリー を考慮することで衝突エネルギーが低下した，スラリーを 考慮しない場合でも各領域で衝突エネルギーに差異がある が、これはミル中でボールが動きやすい領域とそうではな い領域との違いが見えている。 スラリーの存在による衝突 エネルギーの減少量が各領域で異なっており，簡易モデル の結果では 7 20\% の範囲をもつことを示した．図 4 にミ ルの回転数を変更したときの衝突回数の変化を示す. 回転 数が大きいときは衝突回数がボールサイズに比例した。一 方, 回転数が小さいときはボールサイズが小さくなると, 衝突回数が比例関係から外机て減少する条件があった。こ れは, ボールが小さいときはミルの攪拌ピンへの衝突が複 雑になり, ボールの運動が単純な傾向から外れるためと推 測される。

ミル内のボール運動を実験的に把握することは困難なた め, シミュレーションからプロセス改善のヒントとなる知 見を得ることは重要である。粉䂗性の予測能力を向上させ るためには，砕料がミル中でどのような滞留状態にあるか 


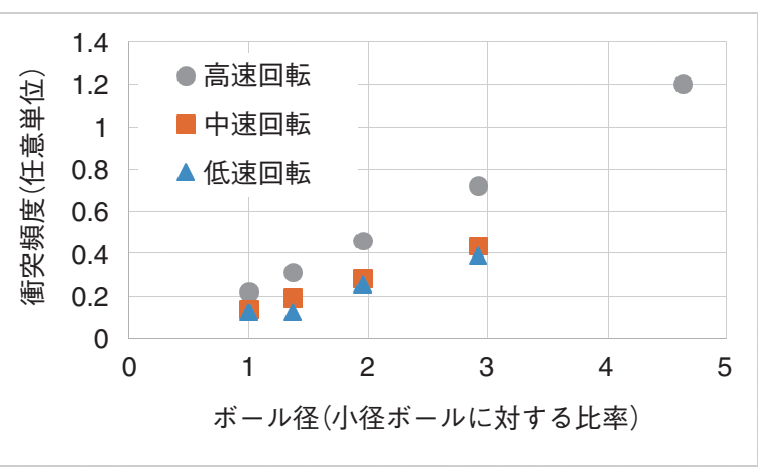

図 4 衝突回数と回転数の関係

も考慮する必要があると考えている.

\section{3. 給粉シミュレーション}

\section{1 動向}

給粉工程で粉末が成型用金型のキャビティに充填される が，焼結後の部品の品質を安定させるにはキャビティに対 する粉末充填のばらつきを小さく抑えることが課題であ る、粉末は粒径分布をもつため通常, 細粒が粉箱の下部に 集まり偏析しており, キャビティへの充塡もその偏析状態 が反映されてしまう。加えて，粉箱内の粉末が減ってくる と偏析状態が変化してしまい, ばらつきの原因となってい る。すでに粉末充塡方法は多くの先行技術が報告されてい るが，沉用的に適用できる方法は抢そらく発見されていな い. 著者らは粉箱抢よびキャビテイ内の粉末状態を可視化 することで, 粉末充填方法の高度化にヒントが得られると 考えており，給粉シミュレーションの開発を進めてきた。 給粉シミュレーションは国内外で盛んに研究されており, すでに多くの事例が報告されている ${ }^{15)}$. Guo は DEM シミ ユレーションと流体計算の連成解析によりキャビテイ内で 粉末が空気を押し出す，いわゆる空気置換現象をシミュレ 一トしている ${ }^{15)}$ ，著者らは，実プロセスの条件出しを念頭 に置き，製造拠点でもシミュレーションを活用できる仕組 みの構築を目指しており，LIGGGHTSを利用したシミュ レーションシステムの開発と解析の事例を報告する.

\subsection{LIGGGHTS を利用した給粉解析システム}

LIGGGHTS の入カファイルは，すべてテキスト形式で 書かれる. Python などのプログラミング言語を用いれば, テキスト中に書かれているパラメータ值を書き換えて LIGGGHTS を実行できるため, 条件違いの計算は自動実 行することができる。 さらに，可視化にオープンソースの 可視化ソフトウエア Paraview ${ }^{16)}$ を利用すれば，充填状況 を示す画像デー夕も作成できる。解析処理も自動化処理に 加えれば，給粉シミュレーションの一連の作業を半自動的 に処理するが可能となる。これら処理の関係を図 5 に示 した，既存のッールや習得が容易なプログラミング言語を 活用することで，開発工数を抑えて給粉シミュレーション の仕組みを構築することに成功した。

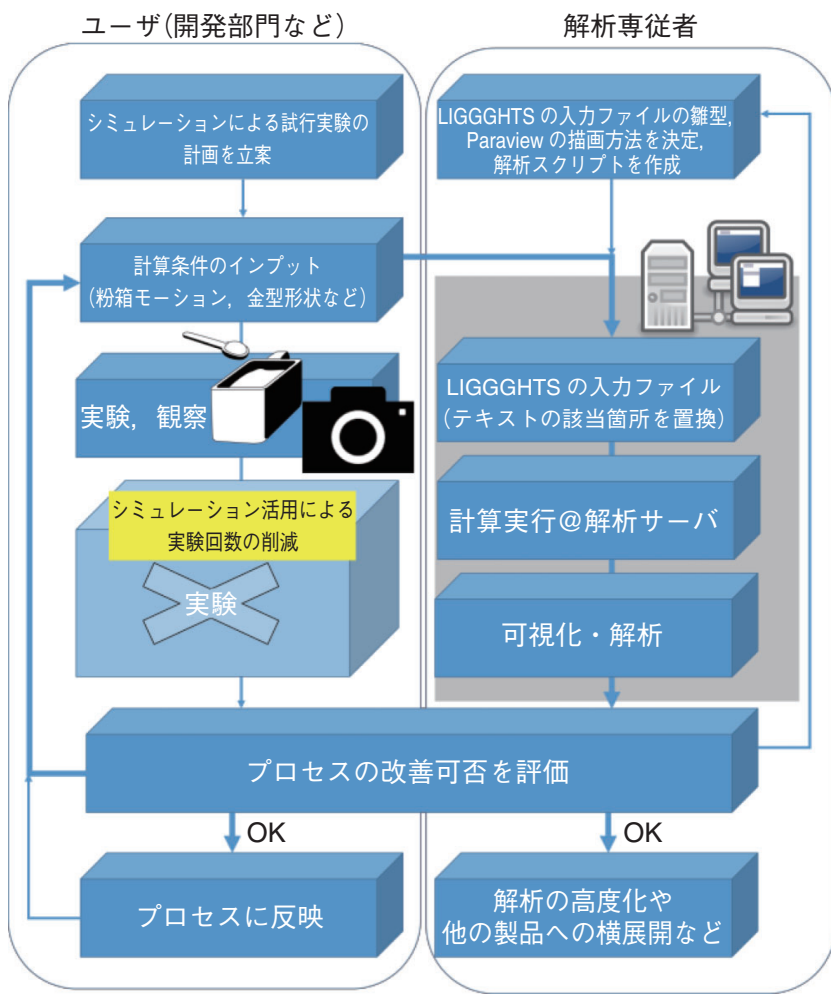

図 5 給粉シミュレーションのフロー

\section{3 粉末挙動の解析結果}

図 6 はキャビティに充塡された粉末が粉箱のどの場所 に位置していたかを示している. 充填前の粉箱内の粒子に 対して高さ方向の初期座標に応じて色付けした，粉箱の隅 に存在した粒子がキャビテイに充填されることが明らかに なり, 給粉を繰り返せば粉箱内の偏析が拡大していき, 粉 末充填に変動をもたらす要因になると予想される。本稿で は詳細デー夕を省略するが，キャビテイ内の粒径分布を実 測と比較すると，粗粒は抄拉よそ傾向が合っているが，細 粒はずれが生じており, 空気置換の影響が出ていると推測 される知見も得られている。給粉シミュレーションの精度 向上には，DEM シミュレーションと流体計算の連成解析 が必要と考えている。

\section{4. 結言}

本稿では，ボールミルおよび給粉工程を計算対象として オープンソースソフトウエア LIGGGHTS の適用事例を紹 介した，並列計算機能が実装されているため，スーパーコ ンピュー夕に移植することで膨大な粒子数を含むモデルも 計算できるようになった。ソースコードを改良すること で，所望の粉体モデルを追加実装することや Python を使 って可視化ソフトと連携させることができ，拡張性に優れ ることも示した，今後，DEM シミュレーションを仮想実 験ツールとして上手に使う方法を検討していきたい，将来 的には，シミュレーション結果をデータベース化し，デイ ープラーニングや AI の技術を活用して, 最適なプロセス 条件を提案できるシステムの構築も目指したい， 


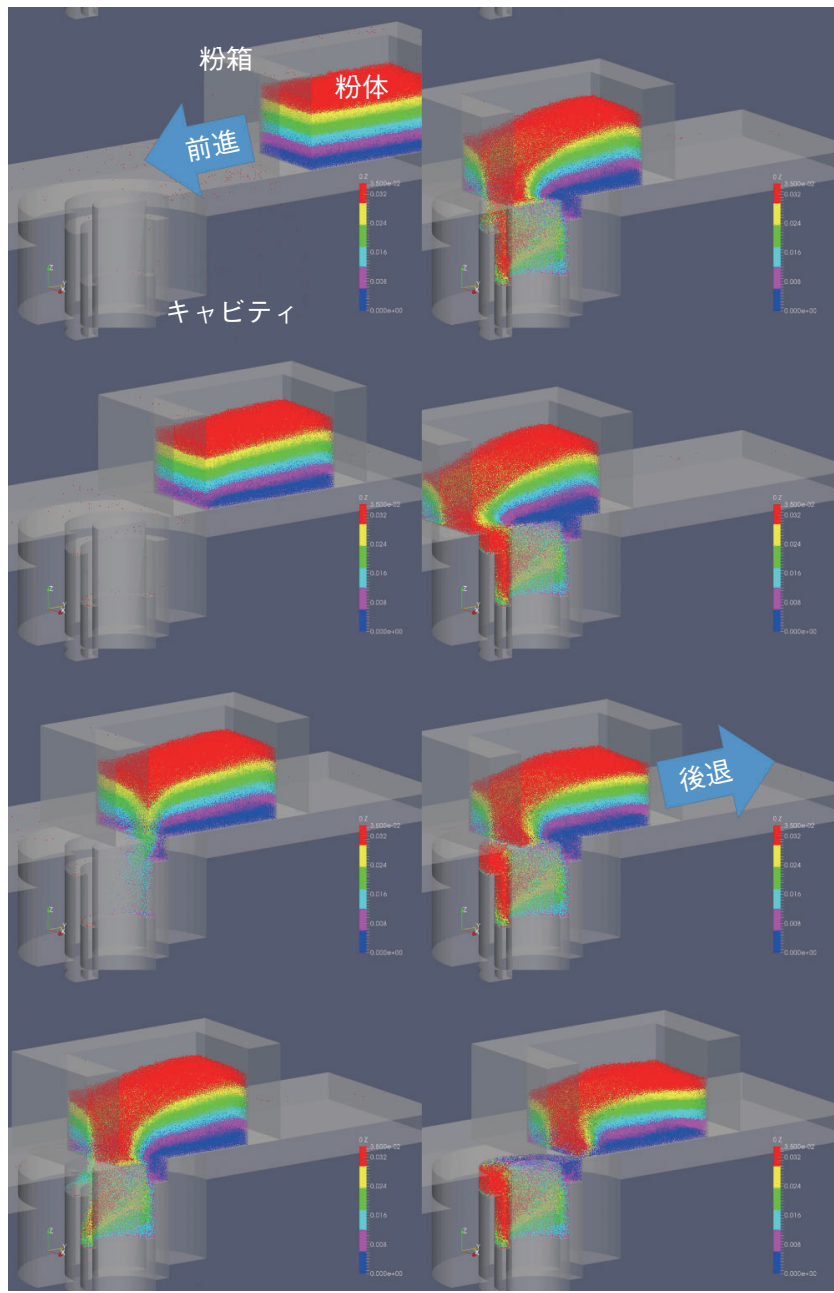

図 6 給粉シミュレーション結果. 粒子の色付けは充填前の高さを 表す.

\section{5. 謝}

\section{辞}

本研究成果の一部は，大阪大学サイバーメディアセンタ 一のスーパーコンピュータシステム SX-ACE を利用して 得られたものである。

\section{参 考 文 献}

1) P.A. Cundall and O.D.L. Strack: A discrete numerical model for granular assemblies, Géotechnique, 29 (1979) 47.

2) 粉体工学会編：粉体シミュレーション入門—コンピュータで粉 体技術を創造する，産業図書，（1998）。

3) 大塚順：個別要素法による粉粒体シミュレーションへの OpenMP 並列の適用, 2012 年ハイパフォーマンスコンピューテ イングと計算科学シンポジウム発表資料.
4）大塚順：個別要素法シミュレータ LIGGGHTSを用いたボールミ ルの粉砕性予測技術, オープン CAE シンポジウム 2014 発表資 料.

5）大塚順：粉体-流体連成解析によるボールミルの大規模シミュレ ーション, HPCI システム利用課題 利用報告書, hp140085 (2015).

6) M. Sakai et al : Verification and validation of a coarse grain model of the DEM in a bubbling fluidized bed, Chemical Engineering Journal, 244, 15 (2014) 33.

7) W.A. Gray: The Packing of Solid Particles, Chapman and Hall, (1968) 71.

8) C. Lillie and P. Wriggers: Three-dimensional modeling of discrete particles by superellipsoids, Proc. Appl. Math. Mech., 6 (2006) 101.

9) C. Kloss, C. Goniva, A. Hager, S. Amberger and S. Pirker : Models, algorithms and validation for opensource DEM and CFD-DEM, Progress in Computational Fluid Dynamics, 12, Nos. 2/3 (2012) 140-152.

10）首藤史：オープンソース CFD-DEM を用いた球形および非球形 粒子挙動シミュレーション, 日本設計工学会研究発表講演会講 演論文集，秋季，（2016）175.

11）山中秀作, 吉田周平, 山田貴博：個別要素法による粉末の金型 充填シミュレーション, 計算工学講演会論文集 Proceedings of the Conference on Computational Engineering and Science 19, 3p, (2014).

12）曽田力央, 加納純也, 齋藤文良：DEM による媒体擋拌ミル擋拌 ロータのピン形状が媒体運動に及ぼす影響の解析, J. Soc. Powder Technol., Japan, 46 (2009) 180.

13）木村真喜男, 鳴海雅之, 览林智成：離散要素法シミュレーショ ンによるボールミルの設計手法, 住友化学, (2007) 31.

14) Y. Tsuji, T. Kawaguchi and T. Tanaka:Discrete particle simulation of two-dimensional fluidized bed, Powder Technol., 77 (1993) 79

15) Y. Guo : A COUPLED DEM/CFD ANALYSIS OF DIE FILLING PROCESS, The University of Birmingham, 2010, Ph. D. thesis.

16) A. Henderson: ParaView Guide, A Parallel Visualization Application. Kitware Inc., (2007).

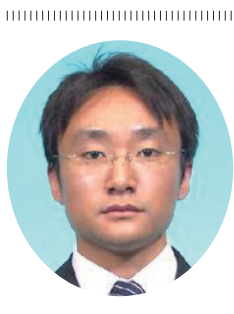

\section{大塚 順}

2007 年大阪大学大学院工学研究科 精密科学 応用物理学専攻精密科学コース修了. 修士. 現 在, 住友電気工業 (株) 解析技術研究センターに 所属。計算力学 (CAE) 技術者国際上級アナリ スト.

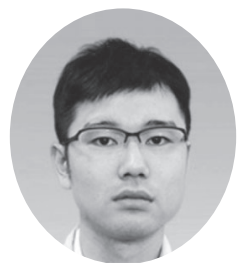

\section{齋藤達哉}

2014 年東北大学大学院工学研究科 知能デバイ ス材料学専攻情報デバイス材料学講座修了, 博 士. 現在，住友電気工業(株)アドバンストマテ リアル研究所に所属。粉末治金の特徵を活かし た磁性材料の開発に従事 